\title{
Age Hardening and Microstructure of ZA84 Magnesium Alloy with the Combined Addition of $\mathrm{Cr}$ and $\mathrm{Bi}$
}

\author{
Ye Jie ${ }^{1,2}$, Lin Xiaoping ${ }^{1,2}$, Dong Yun ${ }^{1,2}$, Teng Fei ${ }^{1,2}$, Sun Guifang ${ }^{1,2}$, Han Jie \\ ${ }^{1}$ Northeastern University, Shenyang 110819, China; ${ }^{2}$ Key Laboratory of Dielectric and Electrolyte Functional Material Hebei Province, \\ Northeastern University at Qinhuangdao Branch, Qinhuangdao 066004, China
}

\begin{abstract}
The age hardening and microstructure of ZA84 magnesium alloy with the combined addition of $\mathrm{Cr}$ and Bi was studied by SEM and HRTEM. The results show that a trace amount of $\mathrm{Cr}$ and $\mathrm{Bi}$ has a significant enhancement effect on the hardness of aging. When the ZA84-0.2Cr-0.5Bi alloy was aged at $160{ }^{\circ} \mathrm{C}$, during the early aging period, the matrix has serious lattice distortion and a large number of crystal defects. The microstructure at the peak aging consists of a large number of rod-like or blocky $\beta_{1}^{\prime}-\mathrm{MgZn}_{2}$ phases and granular $\mathrm{Bi}_{2} \mathrm{Mg}_{3}$ phases, and the peak hardness $\mathrm{HV}$ value is $924.8 \mathrm{MPa}$. When ageing proceed, the precipitates coarsening results in the hardness value reduction.
\end{abstract}

Key words: ZA84-0.2Cr-0.5Bi alloy; crystal defect; age hardening; strengthening phase

Strengthening and toughening is an important research problem in magnesium alloy, which restricts the application of magnesium alloy to a great extent ${ }^{[1-4]}$. Mg- Zn solid solution has the metastable solubility gap and age hardening characteristics, which has become a hot research topic in the present study. During aging heat treatments, the aging sequences of $\mathrm{Mg}-\mathrm{Zn}$ alloy are as follows: SSSS $\rightarrow$ G. P. zone/ $\beta_{1}^{\prime}$ (rods or blocky $\mathrm{MgZn}_{2}$ or $\mathrm{Mg}_{4} \mathrm{Zn}_{7}, \perp[0001]_{\mathrm{Mg}}$ ) $\rightarrow$ $\beta_{2}^{\prime}$ (laths $\mathrm{MgZn}_{2} \perp[0001]_{\mathrm{Mg}}$ or coarse plates $\mathrm{MgZn}_{2} / /$ $\left.[0001]_{\mathrm{Mg}}\right) \rightarrow \beta\left(\mathrm{Mg}_{2} \mathrm{Zn}_{3}\right)^{[5,6]}$. It is generally believed that the G.P. zone and $\beta_{1}^{\prime}-\mathrm{MgZn}_{2}$ is the most effective strengthening phase in Mg-Zn alloy. However, the aging hardening effect of $\mathrm{Mg}-\mathrm{Zn}$ binary alloy is not satisfying. This is due to the low precipitation density and poor thermal stability of the $\beta_{1}^{\prime}$ phase, so it is easy to grow up into laths or coarse plates $\beta_{2}^{\prime}$ phase. The $\beta_{2}^{\prime}$ phase can significantly reduce the strength of $\mathrm{Mg}-\mathrm{Zn}$ based alloy. Therefore, how to strengthen the aging hardening effect of $\mathrm{Mg}$-Zn-based alloys has become a research hotspot. It is well known that adding some alloy elements to improve the nucleation rate and precipitate density is an effective method to improve the aging strength of $\mathrm{Mg}-\mathrm{Zn}$-based alloys. Buha et al have studied the effect of $\mathrm{Cr}^{[7]}$,
$\mathrm{Ba}^{[8]}$ and $\mathrm{Ti}^{[9]}$ on the microstructure and age hardening of $\mathrm{Mg}-\mathrm{Zn}$ alloy. The results revealed that a trace amount of $\mathrm{Cr}$, $\mathrm{Ba}$ or $\mathrm{Ti}$ are exceptionally effective in enhancing the age hardening processes of $\mathrm{Mg}-\mathrm{Zn}$ alloy by stimulating the nucleation of the precipitates. Mendis et al ${ }^{[10]}$ have studied effect of $\mathrm{Li}$ addition on the age hardening response and precipitate microstructures of $\mathrm{Mg}-2.4 \mathrm{Zn}-0.16 \mathrm{Zr}$ alloy. The results showed that $\mathrm{Li}$ improved the kinetics of precipitation hardening and the number density of the precipitates in the $\mathrm{Mg}-2.4 \mathrm{Zn}-0.16 \mathrm{Zr}$ alloy. Although the Mg-Zn alloy containing $\mathrm{Cr}, \mathrm{Ba}, \mathrm{Ti}$ or Li has a higher precipitation density and aging hardness than $\mathrm{Mg}-\mathrm{Zn}$ binary alloy, the size of effective strengthening phase $\beta_{1}^{\prime}$ remains relatively coarse. Therefore, the aging hardening response of the $\mathrm{Mg}$-Zn-based alloys needs to be further enhanced. In the recent years, many research groups believe that combined addition of above 2 or 3 trace element is the future development of the aged Mg-Zn-based alloys. Zhang et al ${ }^{[11]}$ have studied the effect of artificial aging on microstructure of the $\mathrm{Mg}-4.5 \mathrm{Zn}-4.5 \mathrm{Sn}-2 \mathrm{Al}$ alloy. The results indicated that there are some types of precipitates in the microstructure of the alloy and the peak hardness HV can increase to more than $900 \mathrm{MPa}$.

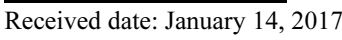

Foundation item: National Natural Science Foundation of China (51675092); Hebei Province Natural Science Fund (E2014501123)

Corresponding author: Lin Xiaoping, Ph. D., Professor, School of Materials Science and Engineering, Northeastern University, Shenyang 110819, P. R. China, Tel: 0086-335-8056792, E-mail: lxping3588@163.com 
Bhattacharjee et al ${ }^{[12]}$ have studied the effect of $\mathrm{Ag}$ and $\mathrm{Ca}$ additions on the age hardening response of $\mathrm{Mg}-\mathrm{Zn}$ alloys. Their research showed that the peak hardness of the alloy with the combined addition of $\mathrm{Ag}$ and $\mathrm{Ca}$ is much higher than that of the binary and ternary alloys. In addition, Oh-ishi's ${ }^{[13]}$ and our previous ${ }^{[14]}$ research indicated that the $\mathrm{Mg}-\mathrm{Zn}-\mathrm{Al}$ alloy has more variations of the morphology and finer distribution of precipitates than $\mathrm{Mg}-\mathrm{Zn}$ alloy. Thus, we studied the age hardening and microstructure of $\mathrm{Mg}-8 \mathrm{Zn}-4 \mathrm{Al}$ alloy (ZA84 magnesium alloy) with the combined addition of $\mathrm{Cr}$ and $\mathrm{Bi}$. Depending on the role of $\mathrm{Cr}^{[7]}$ in promoting nucleation of the precipitates and $\mathrm{Bi}^{[15,16]}$ in inhibiting the growth of the $\beta_{1}^{\prime}-\mathrm{MgZn}_{2}$ phase, the ZA84 magnesium alloy containing $\mathrm{Cr}-\mathrm{Bi}$ element has a better effect on age hardening response than the ternary ZA84 magnesium alloy.

\section{Experiment}

An alloy having a composition ZA84-0.2Cr-0.5Bi (wt\%) was prepared from pure magnesium, pure chromium, pure bismuth and $\mathrm{Mg}-\mathrm{Zn}-\mathrm{Al}$ pre-alloys, which was prepared from pure components in the same manner, with an electrical resistance furnace under protective $0.1 \mathrm{SF}_{6}-99.9 \mathrm{CO}_{2}(\mathrm{wt} \%$ ) atmosphere. About $500 \mathrm{~g}$ melts were heated to $720^{\circ} \mathrm{C}$, held for $20 \mathrm{~min}$ and then poured into a $15 \mathrm{~mm}$ (dia.) $\times 200 \mathrm{~mm}$ pre-heated permanent mould (the preheating temperature 500 ${ }^{\circ} \mathrm{C}$ ) made of steel. The as-cast alloys were solid solution treated at $350{ }^{\circ} \mathrm{C}$ for $12 \mathrm{~h}$ prior to quenching in cold water. Artificial aging (T6) was performed at $160{ }^{\circ} \mathrm{C}$ in an oil bath. The age hardening value was obtained with a Vickers hardness tester (HXD-1000) under a load of $500 \mathrm{~g}$. The final value reported here was averaged from at least 10 measurements. The scanning electron microscope (SEM) images were obtained by ZEISS Supra 55. The specimens for high resolution transmission electron microscope (HRTEM) were obtained from aged material using a Precision Ion Polishing System (Gatan 691). The HRTEM images were obtained by JEOL JEM-2010FEF at $300 \mathrm{kV}$.

\section{Results and Discussion}

\subsection{Age hardening}

The age hardening curves of ZA84 magnesium alloy and ZA84-0.2Cr-0.5Bi alloy aged at $160{ }^{\circ} \mathrm{C}$ are shown in Fig. 1. The two curves indicate that the age hardening process of the ZA84 magnesium alloy and the ZA84-0.2Cr- 0.5Bi alloy follow a similar pattern: the hardness rises in the earlier stage and then declines with prolonging age time. For the ZA84 alloy, the hardness $\mathrm{HV}$ value in the as-quenched samples is $\sim 670 \mathrm{MPa}$. When this alloy is aged at $160{ }^{\circ} \mathrm{C}$, the kinetics of precipitates in the early aging period $(0 \sim 20 \mathrm{~h})$ is much lower than that of ZA84-0.2Cr-0.5Bi alloy. When aging time is $64 \mathrm{~h}$, a peak hardness $\mathrm{HV}$ value of $861.2 \mathrm{MPa}$ is obtained. The ZA84 alloy only shows a small amount of age hardening $(\triangle \mathrm{HV} \approx 90 \mathrm{MPa})$. For the ZA84-0.2Cr-0.5Bi alloy, a hardness

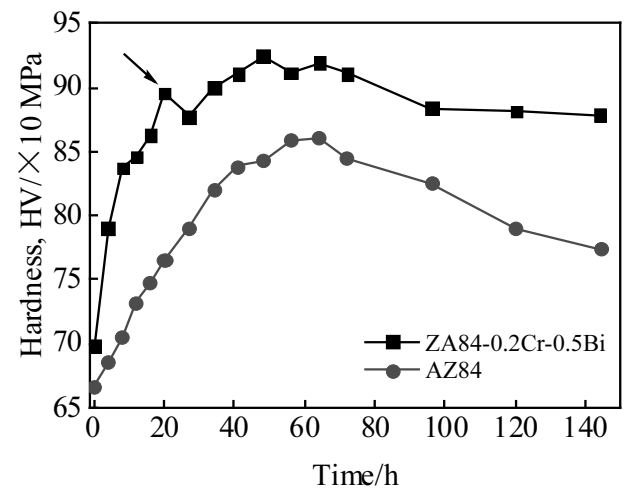

Fig.1 Age hardening curves of ZA84 alloy and ZA84-0.2Cr-0.5Bi alloy aged at $160{ }^{\circ} \mathrm{C}$

$\mathrm{HV}$ value of $\sim 700 \mathrm{MPa}$ is obtained in the as-quenched samples. When the alloy is subjected to aging at $160^{\circ} \mathrm{C}$, the kinetics of precipitates at initial stage $(0 \sim 20 \mathrm{~h})$ is considerably accelerated and the alloy reaches $96.86 \%$ of its maximal hardness level after $20 \mathrm{~h}$ (arrowed). The hardness HV reaches the peak $(924.8 \mathrm{MPa})$ after $48 \mathrm{~h}$ of ageing, and then decreases slightly with the prolonging of aging time. Therefore, although the content of $\mathrm{Cr}$ and $\mathrm{Bi}$ is at a trace level, they have a significant enhancement effect on the hardness of aging.

\subsection{Microstructures}

The HRTEM images of the microstructure of ZA84-0.2Cr$0.5 \mathrm{Bi}$ alloy aged at $160^{\circ} \mathrm{C}$ for $8 \mathrm{~h}$ are shown in Fig.2. There is no precipitates found in the microstructures of alloy, but the matrix has severe moiré fringes and lattice distortion. Some moiré fringes (arrows) with different sizes are visible in Fig.2a. These moiré fringes indicate that some precipitates were generated in the early aging period. The lattice distortion Frank loops and stacking faults around the dislocation in the matrix can be clearly observed (Fig.2b). This may be that $\mathrm{Cr}$ has an extremely low solubility, and it is very likely that in the initial stage of ageing or possibly even during quenching, $\mathrm{Cr}$ dissociated from the magnesium solid solution, thereby providing suitable (heterogeneous) nucleation sites for the aggregation of $\mathrm{Zn}$ or $\mathrm{Bi}$ atoms (and vacancies) ${ }^{[7]}$. It is well known that solute atoms are easier to aggregate at the crystal defects; therefore, the number of crystal defects in the matrix is increased, and the nucleation rate of the subsequent precipitates is promoted obviously. In addition, numerous lattice contractions shown in the rectangular regions $\mathrm{A}$ and lattice expansions shown in the rectangular regions $\mathrm{B}$ can also be observed in Fig.2b.

The peak aged microstructure of ZA84-0.2Cr-0.5Bi alloy aged at $160{ }^{\circ} \mathrm{C}$ for $48 \mathrm{~h}$ are shown in Fig.3. These images are taken with the electron beam parallel to the $[2 \overline{1} \overline{1} 0]_{\alpha}$ direction. Fig. 3a shows the microstructure consisting of numerous rod-like precipitates that are $150 \sim 300 \mathrm{~nm}$ in length and growing along the $[0001]_{\alpha}$ direction, blocky precipitates that are growing along the $[0 \overline{1} 10]_{\alpha}$ direction, and a small amount 


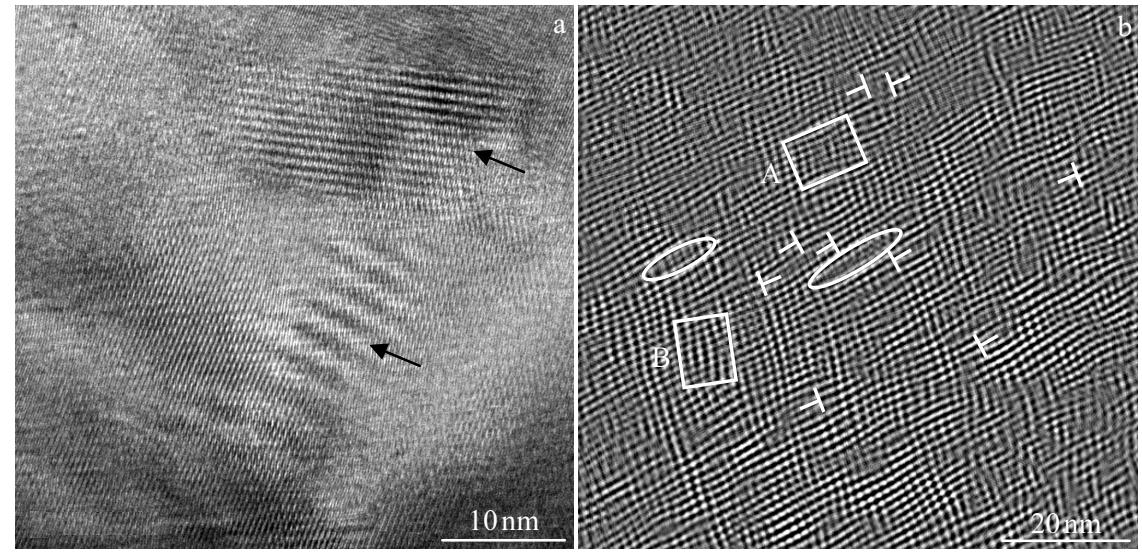

Fig. 2 HRTEM images of the microstructure of ZA84-0.2Cr-0.5Bi alloy aged at $160^{\circ} \mathrm{C}$ for $8 \mathrm{~h}$

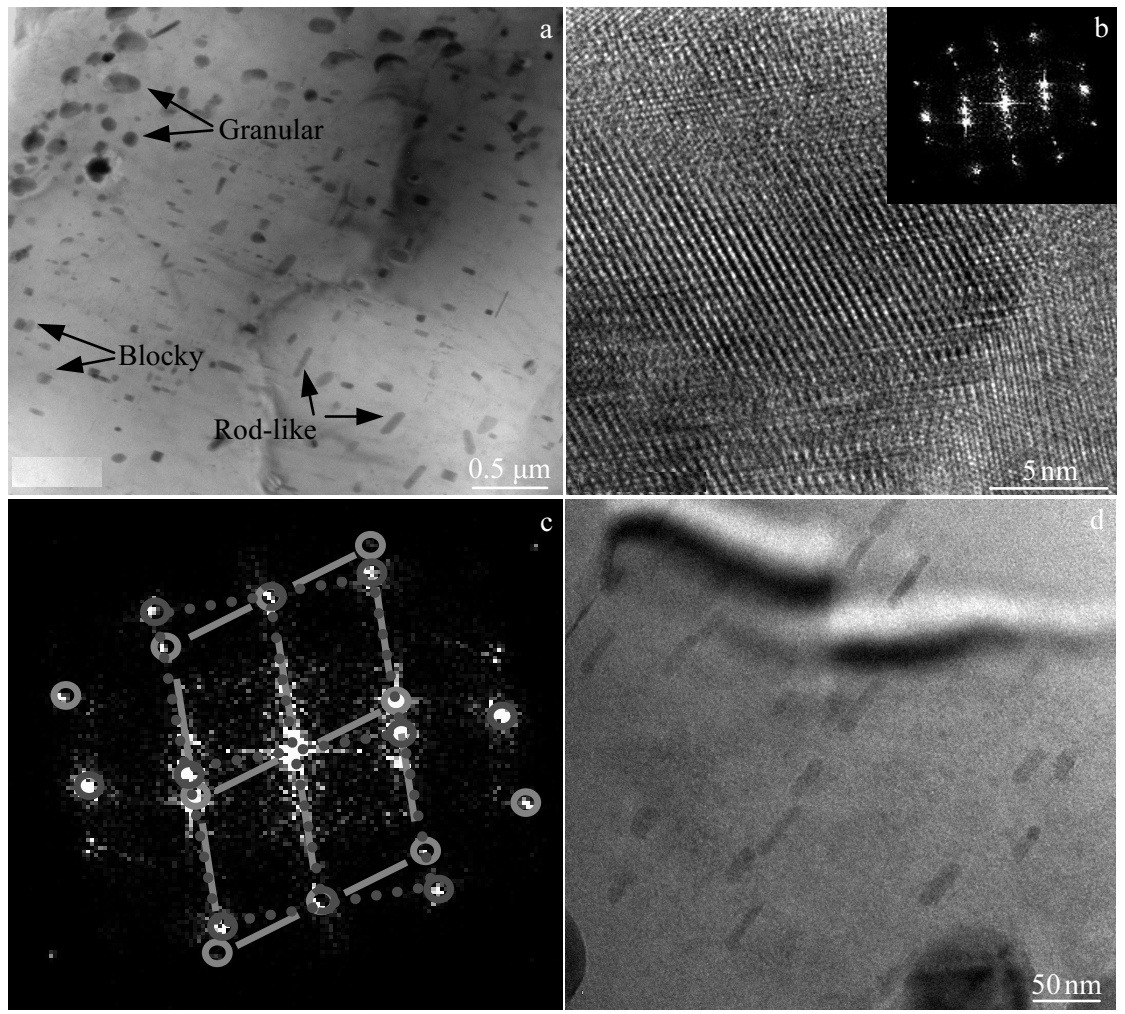

Fig.3 HRTEM images of ZA84-0.2Cr-0.5Bi alloy aged at $160{ }^{\circ} \mathrm{C}$ for $48 \mathrm{~h}$ : (a) rod-like precipitates of $150 \sim 300 \mathrm{~nm}$ in length, (b) HRTEM image of the granular precipitate, (c) ( $01 \overline{12})_{\mathrm{Bi}_{2} \mathrm{Mg}_{3}} / /(0 \overline{1} 10)_{\alpha}$ and $[\overline{2} 4 \overline{2} 3]_{\mathrm{Bi}_{2} \mathrm{Mg}_{3}} / /[2 \overline{1} \overline{1} 0]_{\alpha}$, and (d) $\beta_{1}^{\prime}-\mathrm{MgZn}_{2}$ phases of $30 \sim 50 \mathrm{~nm}$ in length

of granular precipitates. These rod-like and blocky precipitates correspond well to the $\beta_{1}^{\prime}-\mathrm{MgZn}_{2}$ phases, which are typical for the artificially aged condition of Mg-Zn based alloys ${ }^{[17]}$. The HRTEM image of the granular precipitate is shown in Fig.3b. The FFT pattern inserted in Fig. 3b obtained from the granular precipitates could be indexed consistently according to a hexagonal structure, with lattice parameters $a=0.468 \mathrm{~nm}$, $c=0.742 \mathrm{~nm}$. This structure of the granular precipitates is similar to that of the $\mathrm{Bi}_{2} \mathrm{Mg}_{3}$. Fig. $3 \mathrm{c}$ shows that the granular $\mathrm{Bi}_{2} \mathrm{Mg}_{3}$ precipitate has the orientation relationship with the

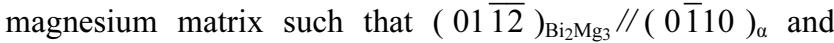
$[\overline{2} 4 \overline{2} 3]_{\mathrm{Bi}_{2} \mathrm{Mg}_{3}} / /[2 \overline{1} \overline{1} 0]_{\alpha}$. It is worth noting that there are some fine and rod-like $\beta_{1}^{\prime}-\mathrm{MgZn}_{2}$ phases in the microstructure of the alloy at a high magnification. These $\beta_{1}^{\prime}-\mathrm{MgZn}_{2}$ phases are $30 \sim 50 \mathrm{~nm}$ in length and grow along the $[0001]_{\alpha}$ direction, and they can effectively improve the aging hardness of the ZA84-0.2Cr-0.5Bi alloy (Fig.3d).

Fig. 4 shows the microstructure of ZA84-0.2Cr-0.5-Bi alloy aged at $160^{\circ} \mathrm{C}$ for $144 \mathrm{~h}$. As the aging time increases, the size of precipitates increases, and the precipitate free zone (PFZ) 


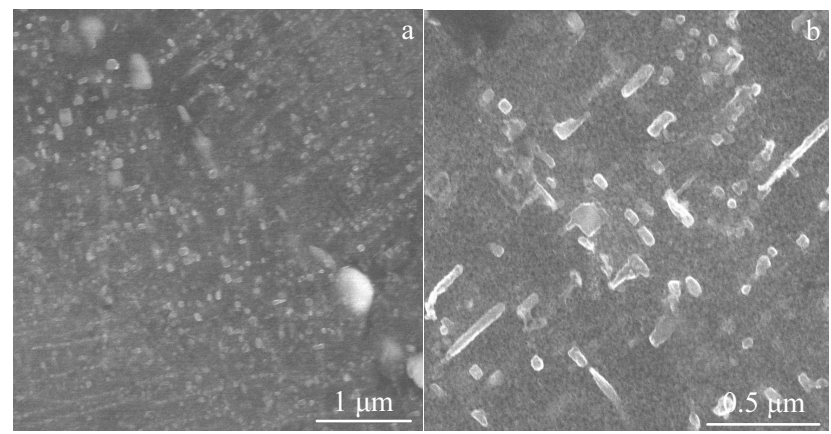

Fig.4 SEM microstructure of ZA84-0.2Cr-0.5Bi alloy aged at 160 ${ }^{\circ} \mathrm{C}$ for $144 \mathrm{~h}$

is observed along grain boundaries (Fig.4a). The rod-like precipitates are about $500 \mathrm{~nm}$ in length, which is much longer than that of the peak aged microstructure $(48 \mathrm{~h})$. The precipitate coarsening results in the hardness value reduction.

\section{Conclusions}

1) The ZA84-0.2Cr-0.5Bi alloy exhibits rather high hardening rate at initial stage of aging, the hardness $\mathrm{HV}$ reaches the peak $(924.80 \mathrm{MPa})$ after $48 \mathrm{~h}$ of ageing, and then decreases slightly with the prolonging of aging time.

2) For ZA84-0.2Cr-0.5Bi alloy aged at $160{ }^{\circ} \mathrm{C}$, during the early aging period, the matrix has serious lattice distortion and a large number of crystal defects. The microstructure at the peak aging consists of a large number of rod-like or blocky $\beta_{1}^{\prime}-\mathrm{MgZn}_{2}$ phases and granular $\mathrm{Bi}_{2} \mathrm{Mg}_{3}$ phases. Then precipitate coarsening results in the hardness value reduction when the ageing proceeds.
3) Although the content of $\mathrm{Cr}$ and $\mathrm{Bi}$ is at a trace level, they had a significant enhancement effect on the hardness of aging.

\section{References}

1 Wang X L, Li C R, Guo C P. Acta Metallurgica Sinica[J], 2010, 462: 575 (in Chinese)

2 Ding Wenjiang. Science and Technology of Magnesium Alloy[M], Beijing: Science Press, 2007 (in Chinese)

3 Huang T H, Song P, Zhou H H et al. Rare Metal Materials and Engineering [J], 2016, 45(2): 431 (in Chinese)

4 Zhang D D, Hao X W, Fang D Q et al. Rare Metal Materials and Engineering[J], 2016, 45(9): 2208

5 Shi G L, Zhang D F, Zhao X B et al. Rare Metal Materials and Engineering[J], 2013, 42(12): 2447

6 Gao X, Nie J F. Scripta Mater[J], 2007, 56(8): 645

7 Buha J. Mater Sci Eng A[J], 2008, 492(1-2): 293

8 Buha J. Mater Sci Eng A[J], 2008, 491: 70

9 Buha J. J Alloy Compd[J], 2009, 472: 171

10 Mendis C L, Oh-ishi K, Ohkubo T et al. Mater Sci Eng A[J], 2012, 535: 122

11 Zhang Guanghao, Chen Jihua, Yan Hongge et al. J Alloy Compd [J], 2014, 592: 250

12 Bhattacharjee T, Mendis C L, Oh-ishi K et al. Mater Sci Eng A [J], 2013, 575: 231

13 Oh-ishi K, Hono K, Shin K S. Mater Sci Eng A[J], 2008, 496: 425

14 Lin Xiaoping, Dong Yun, Ye Jie et al. Mater Sci Eng A[J], 2012, 538: 231

15 Sasaki T T, Ohkubo T, Hono K. Scripta Mater[J], 2009, 61: 72

16 Yuan G Y, Sun Y S, Ding W J. Mater Sci Eng A[J], 2001, 308: 38

17 Buha J. Mater Sci Eng A[J], 2008, 489: 127

\title{
复合添加 Cr、Bi 元素的 ZA84 镁合金时效硬化及微观组织研究
}

\author{
叶 杰 ${ }^{1,2}$, 林小娉 ${ }^{1,2}$, 董 允 $^{1,2}$, 滕 飞 ${ }^{1,2}$, 孙桂芳 ${ }^{1,2}$, 韩 杰 $^{1,2}$ \\ (1. 东北大学, 辽宁 沈阳 110819) \\ (2. 东北大学秦皇岛分校 河北省电介质与电解质功能材料重点实验室, 河北 秦皇岛 066004)
}

\begin{abstract}
摘 要: 利用扫描电镜及高分辨透射电镜对复合添加 $\mathrm{Cr} 、 \mathrm{Bi}$ 元素的 ZA84 镁合金的时效硬化及微观组织进行了研究。结果表明: 在 ZA84 合金中复合添加微量的 $\mathrm{Cr} 、 \mathrm{Bi}$ 元素能显著增强合金时效硬化效果。 $\mathrm{ZA} 84-0.2 \mathrm{Cr}-0.5 \mathrm{Bi}$ 合金经 $160{ }^{\circ} \mathrm{C}$ 时效，在时效初期基体存在严重的晶 格畸变并含有数量较多的晶体缺陷。峰时效阶段合金微观组织中析出大量呈棒状或块状的 $\mathrm{MgZn}_{2}$ 相以及粒状的 $\mathrm{Bi}_{2} \mathrm{Mg}_{3}$ 相, 此时合计峰 时效硬度 $\mathrm{HV}$ 达到 $924.8 \mathrm{MPa}$ 。随着时效时间的延长, 沉淀相继续长大并粗化, 其硬度也略有下降。
\end{abstract}

关键词: ZA84-0.2Cr-0.5Bi 镁合金; 晶体缺陷; 时效硬化; 强化相

作者简介：叶 杰, 女, 1986 年生, 硕士生, 东北大学材料科学与工程学院, 辽宁 沈阳 110819, 电话: 0335-8056792, E-mail: yejie9966@163.com 